\title{
ЭКОЛОГИЧЕСКИЕ ИССЛЕДОВАТЕЛЬСКИЕ РАБОТЫ В ДОПОЛНИТЕЛЬНОМ ОБРАЗОВАНИИ ДЕТЕЙ М.А. Надпорожская
}

Биологический факультет, Санкт-Петербургский государственный университет; Дом детского творчества Петродворцового района, Санкт-Петербург, Россия

Эл.nочma:marinta@mail.ru

Статья поступила в редакцию 08.08.2015; принята к печати 10.09.2015

Проведен анализ организации дополнительного образования детей на примере деятельности объединения «Экология» при Доме детского творчества Петродворцового района Санкт-Петербурга с 2005 по 2015 г. Отмечены проблемы, возникающие при работе со школьниками в режиме свободного посещения занятий при современной перегруженности активных учащихся. Обсуждены вопросы вовлечения учащихся в исследовательские работы. Предложены вероятные способы проведения школьных исследовательских работ в условиях дефицита материальной базы, поясняется мотивация выбора тем исследований, возможности формирования рабочих групп с привлечением заинтересованных взрослых (учителей, родителей и специалистов).

Ключевые слова: экология, дополнительное образование детей, преемственность образования, икольные исследовательские работы.

\author{
ECOLOGICAL RESEARCH ACTIVITIES IN THE EXTRACURRICULAR \\ EDUCATION OF SCHOOLCHILDREN \\ M.A. Nadporozhskaya \\ Biological Faculty, Saint-Petersburg State University; \\ Center of Children Creativity, Petrodvotsoviy District, Saint Petersburg, Russia \\ E-mail:marinta@mail.ru
}

The organization of extracurricular education of schoolchildren is exemplified with the activity of the association "Ekologiya" at the Center of Children Creativity of Petrodvortsoviy District of Saint Petersburg in 2005-2015. Problems possible upon working with children who attend studies voluntary being overloaded with schoolwork are highlighted. The issues of recruiting children to research activities are discussed. Feasible approaches to research unsupported with adequate resources are suggested. The reasons of choosing study subjects are explained. The ways of involving parents, schoolteachers and other specialists in workgroups are discussed.

Keywords: ecology, extracurricular education, research at schools, continuing education.

\section{Введение}

Необходимость экологического образования для устойчивого развития общества объявлена на государственном уровне в документах правительства Российской Федерации и Санкт-Петербурга и других субъектов федерации ${ }^{1}$. Анализ состояния экологического образования в Санкт-Петербурге недавно проведен сотрудниками Санкт-Петербургской академии постдипломного педагогического образования [1].

Отмечено, что в соответствии с нормативными документами о непрерывном экологическом образовании для дошкольных учреждений разработаны и реализуются общеразвивающие эколого-биологические программы. В большинстве общеобразовательных учреждений Санкт-Петербурга (92,3\%) экологическая информация включена в базовые предметы естественнонаучного цикла, отдельные курсы эко-

\footnotetext{
${ }^{1}$ Материалы по разработке и учебно-методическому обеспечению Программы формирования экологической культуры, здорового и безопасного образа жизни основной образовательной программы начального, общего образования. URL: http://mon.tatarstan.ru/rus/file/ pub/pub_124010.pdf;

Основы государственной политики в области экологического развития Российской Федерации на период до 2030 года (утв. Президентом РФ от 30 апреля 2012 г.). http://base.garant.ru/70169264/;

Экологическая политика Санкт-Петербурга на период до 2030 года. Постановление Правительства Санкт-Петербурга от 18.06.2013
} № 400. http://www.infoeco.ru/index.php?id=744 логии для старшеклассников есть только в немногих школах (7,7\%). Частично дефицит экологической информации восполняют факультативные занятия, элективные курсы и специализированные кружки.

Существенными проблемами развития экологического образования в средней школе признаны отсутствие отдельного предмета экологии в базисном учебном плане, недостаток кадров со специальной квалификацией, небольшой выбор учебных пособий и бедная материальная база. Отмечено также, что условия для организации экологического образования в школе недостаточны: школьные учителя проводят исследовательские проекты чаще в инициативном порядке, нет общественной мотивации формирования серьезного отношения к экологическим проблемам. Учебно-воспитательная деятельность в области экологии более углубленно проводится в специализированных кружках учреждений дополнительного образования детей (ДОД). Перспективно сотрудничество школ и ДОД. Главная проблема городских образовательных учреждений состоит в том, что не разработана общая программа развития экологического образования в Санкт-Петербурге, и в отсутствии ее финансирования.

Проблемы образования существовали всегда, решать их можно начинать на уровне отдельных 
образовательных учреждений, кружков и личной инициативы. Постоянное место работы автора Санкт-Петербургский государственный университет. Здесь в течение многих лет я вела различные научные темы: изучение динамики органического вещества почв в лабораторных опытах, оценка влияния почвообразующих геологических пород на формирование почв сосновых лесов, исследование экологического состояния производственных и городских территорий, решение вопросов повышения продуктивности сельскохозяйственных растений. Читала лекции по почвоведению, экологии и агрохимии. Проводила практические занятия на стационарах СПбГУ в разных природных зонах. Один учебный год подменяла учителя в школе - раз в неделю вела уроки экологии 7-8-х классах. Совмещая с работой в университете, девять лет назад я начала вести кружок экологии в Доме детского творчества (ДДТ) Петродворцового района. Основное наше направление - школьные исследовательские работы. За эти годы завершили и проводим с участием школьников около 50 исследований по разным темам. В силу сложившейся трудовой биографии автор знаком с проблемами как высшего, так и среднего и дополнительного образования и в этой публикации поделится мыслями о специфике организации педагогического процесса в области экологии и расскажет об опыте проведения школьных исследований в отдельно взятом экологическом кружке.

\section{Особенности реализации экологических исследовательских работ \\ в дополнительном образовании детей}

Существует множество определений понятия «экология». Мы взяли за основу такое: экология это наука о взаимоотношениях живых организмов и их сообществ друг с другом и с окружающей средой. В этом определении четко выражена суть объекта науки экологии: изучение изменения состояния живых организмов и окружающей среды в их взаимосвязи. То есть экология изучает процессы, а не статичные состояния. Фиксировать изменения можно с помощью различных физико-химических методов. Для обработки результатов нужен математический аппарат. Изучение может проводиться от микро- до макроуровня. Это краткое введение вскрывает сложность экологии как интегральной надпредметной науки.

Экология как научная и образовательная область деятельности имеет ряд особенностей, важных как для ученого, так и для преподавателя. При планировании учебно-просветительского процесса надо учитывать эти особенности и правильно расставлять акценты. В целом специфика экологии выражена в таких аспектах:

- научный,

- геополитический,

- культурно-историко-региональный,

- информационно-когнитивный,

- мотивационно-этический.

Рассмотрим более детально, как выражена по перечисленным аспектам специфика экологического образовательного процесса в дополнительном образовании.

\section{Научный аспект}

Влияние технического прогресса на живую природу стало угрожающе велико, поэтому основы экологических знаний необходимы на уровне принятия решений в промышленности, сельском и лесном хозяйствах, в политике и в быту. Еще в 1866 г. термин «экология» был введен Эрнестом Геккелем в качестве названия науки «об отношениях организмов с окружающей средой», где под «средой» подразумевались «в широком смысле все условия существования» как органической, так и неорганической природы. Экология в смысле «наука о состоянии окружающей среды» (environmental science) стала активно развиваться с 70-х гг. прошлого века, когда была осознана опасность глобального влияния промышленности на природу. По этой причине в русском языке толкование термина «экология», хотя в целом сохранилось, но стало расширенным. Без сомнения, экология как наука о взаимосвязи живых организмов и природной среды приобрела особое значение, когда влияние одного вида живых организмов, человека, стало настолько значительным, что выделено в качестве особого средопреобразующего фактора - антропогенного.

Наиболее актуальная проблема экологии - сохранение биосферы Земли пригодной для жизни человека в условиях стремительной антропогенной деградации природной среды. Это может быть обеспечено только при научно обоснованном природопользовании на основе системных экологических исследований. Антропогенное нарушение биотических круговоротов неминуемо сказывается на состоянии окружающей среды. Как правило, она становится неблагоприятной для жизни человека. Но антропогенные вторичные биогеоценозы не всегда являются ущербными с точки зрения поддержания функций биотического круговорота. Биосфера может считаться устойчивой, если возникающие в ней экосистемы будут по средообразующим функциям эквивалентны старым. Основной концепцией экологически безопасной технологии является идея максимальной замкнутости производственных процессов, компенсация приходных и расходных составляющих круговорота. Воплощение данной концепции в жизнь требует знаний существа процессов в ненарушенных системах, количественных представлений о балансе вещества. Количественное изучение круговорота вещества и потока энергии в природных экосистемах (с детальным изучением его трансформации в почве) может предоставить стандарт скомпенсированных обменных процессов, что позволит оценить степень нарушения систем, подвергнутых антропогенным воздействиям [8].

Понимание и знание основных экологических законов сейчас актуально как никогда. За последние десятилетия развитие техники и усложнение технологий привели к обострению эволюционно сложившихся связей в природной среде, вывели человечество на новые уровни формирования экологических рисков и повышения вероятности техногенных катастроф. Урегулирование многих экологических проблем современности зависит от умения специалистов находить оптимальные решения при организации природопользования. Чтобы принять и применить стратегию сохранения среды обитания, не только специалисты-профессионалы должны иметь развитое экологическое мышление, но и все слои населения. 
Интегральный характер научного аппарата и задач экологии выводит ее на особый уровень не только по уровню значимости для сохранения человечества и среды его обитания, но и по сложности восприятия неспециалистами. Экология не только системная наука, обобщающая в изучении процессов биосферы достижения отдельных отраслей наук. Чтобы стать реальной силой, экология должна стать мировоззрением общества. В этом плане при преподавании основ фундаментальной экологии необходимо уделять внимание формированию морально-нравственных и этических качеств аудитории.

\section{Геополитический аспект}

Конференция ООН в Рио-де-Жанейро 1992 г. определила стратегию человечества по устойчивому развитию в XXI веке в мировом масштабе. Будущее России, как и других стран, зависит от успешности решения этих стратегических задач в сложных экологических, политических и экономических условиях. Необъятность просторов и богатство природно-ресурсного потенциала в нашей стране иной раз могут становиться источником мифов об «особом российском пути» [7]. Общность биосферы и единство законов экологии не позволяют поддаваться таким иллюзиям. Ученые и практики нашей страны должны работать над вопросами экологической гармонизации так же, как и все остальные, но с учетом природно-территориальных особенностей. В плане экологического образования это означает, что для подготовки специалистов высокого уровня следует формировать учебные планы с теоретической частью о законах широкого набора биоклиматических зон в евразийских масштабах.

\section{Культурно-историко-региональный аспект}

Постоянно возрастают как количество городов, так и занимаемая ими территория. Площадь воздействия города превышает его территорию в 20-50 раз. Идет загрязнение водной, воздушной и почвенной систем и разбалансировка их функционирования. Возникает проблема необеспеченности мегаполисов природно-ресурсным потенциалом. Городская экосистема подвержена приоритетному влиянию антропогенного фактора и значительно уступает по устойчивости природным экосистемам [2]. Малый биологический круговорот в них, как правило, разомкнут. Устойчивое функционирование искусственных систем можно обеспечить только при постоянном поддерживающем влиянии человека. Об интересе, который вызывает этот вопрос у ученых всего мира, свидетельствует проведение многочисленных национальных и международных конференций и конгрессов, а также ежегодно увеличивающееся число научных публикаций, посвященных мониторингу устойчивости урбоэкосистем.

Эколого-историческая среда всякого города уникальна и требует особого внимания и режима охраны. Санкт-Петербург, часто провозглашаемый культурной столицей России и одним из центров мирового туризма, должен всемерно поддерживать свой особый статус и в плане уровня экологической культуры. При изучении экологии нашего города следует учитывать и его статус самого северного мегаполиса, что делает его среду более уязвимой к антропогенным воздействиям и требующей особого режима охранных мероприятий [4]. Как болезнь легче предотвратить, чем лечить, так и экологические кризисные ситуации лучше не допускать. И тут особенно важно просвещение и образование по вопросам экологии горожан всех возрастов. Программы экологии для дополнительного образования должны обязательно учитывать региональные природные особенности и историко-культурное наследие.

\section{Информационно-когнитивный аспект}

Интегральный характер экологии, базирование на достижениях различных научных направлений делают даже основы этой дисциплины сложными для восприятия. От обучающихся требуется комплекс знаний по разным предметам. Даже на школьном уровне сложность экологических исследований состоит в значительном разнообразии методов, основных базовых знаниях, полученных на химии, физике, математике, биологии, истории и географии. А для участия в школьных международных проектах неплохо бы еще свободно разговаривать на каком-то иностранном языке, хотя бы английском. Такой многообразный синтез, с одной стороны, позволяет повторить школьный материал, с другой, требует определенной сосредоточенности и затраты сил.

С другой стороны, синтетический характер экологии позволяет учащимся при выполнении исследовательских проектов повторить материал основных предметов школьной программы, уяснить практическое применение некоторых разделов пройденных теоретических курсов. То есть в данном случае дополнительное образование осуществляет обратную связь практики и теории. Знания, примененные на практике, закрепляются лучше. Иногда возникает интерес к дополнительному углубленному изучению теории. В таком случае мы получаем активизацию процесса познания, формирование индивидуальной ответственности и компетентностного подхода, результата, который мы должны получить по новым образовательным стандартам обучения [3]. Компетентностный подход, являющийся основной идеей модернизации образования, выдвигает на первое место не информированность ученика, а умение решать проблемы, возникающие в различных жизненных ситуациях. Интегрированный, надпредметный характер экологии как науки, актуальность экологического образования на современном этапе, возможность использования разнообразных форм внеурочной и внеклассной работы выводят экологическое образование в число приоритетных направлений развития современной школы.

\section{Мотивациионо-этический аспект}

Как было отмечено выше, обучение экологии невозможно без формирования особой мировоззренческой и этической позиции личности. Конечно, экологические проблемы города большей частью связаны с ведением городского хозяйства, с работой промышленных предприятий и транспорта. Но есть бытовые функции города, на которые каждый может оказывать влияние. В последние годы активизируются общественные инициативы, проводятся не только разовые акции по сбору мусора с каких-либо территорий, в городе существует экологическое движение «РазДельный Сбор» (http://vk.com/rsbor). Группа этого движения ВКонтакте насчитывает 22415 человек. 
Хотя и сбор мусора в инициативном порядке - это только тенденция, здесь нужны городские проекты в промышленных масштабах. Раздельный сбор мусора - частный случай во множестве других экологических проблем города. Не все вопросы решаются так однозначно и просто. Нет нужного уровня серьезного отношения к экологическим проблемам в обществе в целом, это отмечено в работе по изучению экологического образования в Санкт-Петербурге [1], факт настораживающий.

Основатель экологической этики, американский писатель и ученый-эколог Альдо Леопольд (Aldo Leopold; 1887-1948) считал, что конфликт человека с природой часто рождается вследствие его неумения видеть свою общность с природой. Мотивационноэтический аспект экологии города должен решаться комплексно, дополнительно на уроках литературы и истории в школе.

\section{Адаптациия приемов обучения к разному уровню заинтересованности, мотивачии к обучению и базовых знаний}

«Знания тогда способствуют развитию и остаются с учеником, когда они либо интересны ему, либо полезны (что вполне может совмещаться и совмещается)» [3]. Занятия кружков дополнительного образования дети посещают по желанию. Один из самых трудных этапов в работе кружка экологии - набор группы. Полезно проводить поиски потенциальных учеников вместе со школьными учителями-предметниками, которые знают, кто из учащихся может быть заинтересован в углубленном изучении экологии, кому это может понадобиться для выбора будущей профессии. Обычно на вводных занятиях с потенциальными юными экологами я рассказываю об уже проделанных школьных исследовательских работах. Список отработанных нами тем широк, многие работы можно продолжать, накапливая материалы для более продуктивного анализа. Когото удается увлечь интересным объектом изучения, кто-то приходит «за компанию». Почти все ребята любят принимать участие в конференциях и конкурсах с докладами по работам. На занятиях обычно мы успеваем сделать и практическую часть работ, и разобрать методы, выучить специальные термины, обсудить результаты и выводы. Планируем оригинальные, небольшие по затратам времени исследования, как правило, на территории нашего района. Работы по удаленным объектам, их практическую часть, обычно выполняем в период летних каникул. Четкое планирование работы, ясно определенные цели и задачи помогают ребятам успешно справиться с выполнением исследования. Конечно, роль руководителя в первых исследованиях огромна, но важно создавать «моменты истины», когда часть выводов учащиеся могут сделать сами. Оригинальные работы на актуальные темы экологии города обычно встречают интерес аудитории на конференциях и конкурcax. Это поддерживает желание юных экологов работать дальше. Конечно, все любят получать грамоты и призы, эта позитивная мотивация удачна всегда. Многие ребята рассказывают о своих работах в неформальной обстановке, занимаясь в свою очередь экологическим просвещением.

Уровень подготовки моих учеников бывал разным - от золотых и серебряных медалистов до учени- ков коррекционного класса. Чтобы учесть интересы всех, формирую рабочие группы. Всегда можно подобрать исследовательскую работу по силам и уровню знаний базовых школьных предметов. Работу потом представляем дифференцированно, по уровням требований и конкуренции на конкурсах и олимпиадах. Сильные ученики осваивают новую информацию быстро, могут выполнять относительно сложные исследования. Учащиеся, не уверенные в своих силах, выполняя сокращенные исследования с простыми объектами, повторяют и закрепляют школьный материал, отрабатывают навыки практических измерений, учатся публичным выступлениям и отстаиванию своей точки зрения. При оформлении работ закрепляем или получаем навыки подготовки презентаций к докладам, при описании проведенной исследовательской работы осваиваем навыки работы с литературой и корректного цитирования источников.

В современном огромном потоке информации, диалоговости интернет-общения, увеличения разнообразия дел, которые надо делать быстро и одновременно, школьники не всегда умеют выбирать главное, делать обобщения и выводы. Это явление получило название «клиповое мышление». В отечественной науке пионером употребления термина «клиповое мышление» стал Ф.И. Гиренок ${ }^{2}$, полагая, что понятийное мышление перестало играть важную роль в современном мире. В крайней степени проявления оно приводит к снижению качества образовательного процесса.

То есть педагогу дополнительного образования приходится работать с современными учащимися разных уровней школьной подготовки по базовым предметам, с вероятной склонностью к «кусочно-прерывистому» восприятию информации или клиповому мышлению. Все это надо учитывать при проведении занятий. Не перегружать теорией, использовать яркие образы, как в устном изложении, так и в иллюстрациях к презентациям. Максимально кратко и логично выстраивать беседы об изучаемых объектах. Задавать вопросы и создавать ситуации, когда ребятам захочется проявить инициативу, отличиться.

Хорошо помогает такое положительное стимулирование, как устная похвала. Ведь оценок за кружковую работу я не выставляю. Именно отсутствие отрицательных оценок при выполнении практических работ помогает некоторым неуверенным в своих силах и привлекает на занятия.

В экологических исследовательских проектах можно объединять учащихся разного уровня подготовки. В исследованиях всегда найдется работа и для «лаборантов», и для «инженеров», и для «мыслителей». Важно убедить команду, что успех не в личном первенстве, хотя и в нем тоже, но не это главное. В экологических работах более ценен результат, выражающийся в улучшении охраны природных объектов или исправлении нарушений городской среды, формировании бережного отношения к природным ресурсам. Поэтому в команде каждый ценен, каждый функционален.

Следование интересам учащихся в выборе объектов для работ, оригинальные разработки программ школьных исследований, успех на конференциях, соревнованиях и олимпиадах, выбранных «по плечу» для каждого участника экологических проектов,

См.: Семеновских Т.В. «Клиповое мышление» - феномен совре менности. http://jarki.ru/wpress/2013/02/18/3208/ 
формирование навыков командной работы, взаимовыручки и поддержки делают процесс обучения в кружке дополнительного образования полезным и интересным.

Перейдем к примерам педагогической работы в экологическом кружке. В ДДТ Петродворцового района наша структура названа объединение «Экология».

\section{Пример реализации экологического образовательного процесса в дополнительном образовании. Объединение «Экология»}

Программа и общчие направления работь объединения «Экология》

Объединение «Экология» действует под руководством автора с 2005 г. Программа работы построена как теоретико-практическая. Экспериментальная деятельность школьников по изучению экологических характеристик окружающей среды в системе дополнительного образования должна поддерживать и развивать знания, полученные в ходе обучения общеобразовательным дисциплинам: биологии, географии, химии, физики и математики. То есть выполняется принцип преемственности: теоретические знания, полученные на школьных уроках, применяются на практике.

В ходе работы по программе учащиеся знакомятся с методами экологического анализа, получают представление о деятельности лаборанта-эколога, понятие о прикладных аспектах законов химии, физики, математики в экологии. Особое внимание уделяется обучению практическим навыкам работы с природными объектами. В основу программы положен мой опыт образовательно-исследовательской деятельности по экологии Петродворцового района. Программа курса является авторской, составлена с учетом особенностей обучения детей средней школы и выстроена как практическая поддержка общеобразовательных программ по географии, химии, физике и биологии.

\section{Задачи программы}

Образовательные

1) расширить и углубить базовые знания учащихся по химии, географии, краеведению;

2) научить определять свойства природных объектов, критерии оценки их качества;

3) обучить началам экологического анализа качества природных объектов;

4) развить общие навыки химико-аналитической работы.

\section{Развиваюшие:}

Развивать познавательную активность и самостоятельность.

\section{Воспитательные:}

Мотивировать отношение к объектам окружающей среды как к исчерпаемым природным ресурсам.

Предусмотрено использование различных форм учебных занятий: групповые формы, практикумы, экскурсии, исследовательские проекты. Используя различные формы и методы обучения, данная программа позволяет формировать универсальные (метапредметные) умения и навыки, такие как:
- учебно-организационные (выбирать наиболее рациональную последовательность выполнения учебной задачи, оценивать свою работу в сравнении с существующими требованиями);

- учебно-логические (систематизировать информацию, искать пути решения учебных и реальных проблемных ситуаций);

- учебно-информационные: представление информации в различных формах (письменная и устная) и видах (рефераты, исследовательские работы, стендовые доклады, интернет-презентации); работа с текстом и внетекстовыми компонентами;

- учебно-коммуникативные (выступать перед аудиторией, придерживаясь определенного стиля при выступлении, соблюдая логику темы; уметь вести дискуссию; отвечать на вопросы, отстаивать свое мнение).

Начальные знания по экологии включены во многие базовые школьные курсы. Но в курсе обязательных школьных предметов недостаточна практическая компонента. Как раз это и компенсируется в учебных исследовательских проектах.

Нами в процессе выполнения исследований накоплен богатый экспериментальный материал, полезный для улучшения качества жизни горожан, разработаны авторские программы по экологическому образованию для школьников, наглядное пособие для игрового занятия по знакомству с почвой «Черный чемоданчик». В период с 2005 по 2015 г. проведены и находятся в работе более 50 школьных исследовательских работ. За эти годы около 120 учащихся объединения «Экология» выступали с докладами на молодежных конференциях районного, городского, всероссийского и международного уровней, занимали призовые места в экологических и биологических олимпиадах. Список тезисов работ, опубликованных в материалах молодежных конференций, приведен в Приложении.

Недавно мы ввели новую форму эколого-просветительной деятельности - экологические экскурсии, подготовленные учащимися объединения «Экология» для сверстников или для младших школьников. В наших работах активное участие принимают учителя-предметники и иногда родители ${ }^{3}$.

Значительное внимание в школьных исследовательских работах уделено почвам. В базовом школьном курсе по географии теме «Почвы России» посвящены всего 4 параграфа в учебниках 7 или 8 классов (по разным программам), которые, как правило, «проходят» за два урока. Этого времени мало для изучения такого сложного, многофункционального,

${ }^{3}$ Например, в Международный день растений 18 мая 2013 г. были проведены такие экскурсии:

- Школа 412. «Тайны химии раннецветущих растений - первые шаги на пути открытий». Соруководителем работы была Н.В. Лебедева. Экскурсовод: Е. Дубинина (9 класс). Проведена экскурсия для учеников 4 класса школы 416.

- Школа 416. «Первоцветы Пролетарского парка Петергофа и интродукция раннецветущих растений на школьном дворе». Соруководителями работы были М.В. Агеева и А.С. Красова. Юные экскурсоводы (6 класс) Е. Красова и А. Брежнева провели две экскурсии для учащихся 4-х классов.

- Петергофская гимназия императора Александра II. «Первоцветы Верхнего парка Петергофа (Early Spring Flowers in Peterhof Upper Garden)» - на русском и английском языках. Экскурсоводы-ведущие: Е. Заболоцких, К. Филимонова, В. Кошурина, А. Пожидаева. Соруководители от гимназии: Н.Д. Каверзова - руководство подготовкой сообщений на русском языке, Л.В. Сулыгина - руководство подготовкой сообщений на английском языке, составление мини-словаря по биологии раннецветущих растений. 
динамического и пространственно гетерогенного объекта, как почва. Между тем, это важные базовые знания, необходимые для проведения и организации работ в сельском, лесном, промышленном и городском хозяйстве. Школьные исследования, проводимые сверх программы, могут помочь ребятам расширить понятие о почвах.

Многие работы выполнены при совместном руководстве со школьными учителями ${ }^{4}$. Проводя экологические работы, мы часто обращаемся за консультациями к научным сотрудникам биолого-почвенного факультета.

\section{Расширение информационного пространства объединения «Экология»}

Чтобы еще шире раскинуть информационную сеть для внутренней коммуникации и пропаганды экологических знаний, мы начали вести сайт объединения «Экология». Адрес сайта: http://ecology.url.ph/5. Сайт построен на основе многофункциональной системы управления сайтом DataLife Engine и размещен на бесплатном хостинге. Сайт отличается современным оптимизированным и минималистичным дизайном. Сайт имеет страницы: «Главная», «Новости», «О программе», «Наши работы», «Фотоархив», «Это интересно», «Библиотека», «Полезные ссылки». С главной страницы открывается путь в остальные разделы сайта. На странице «Новости» рассказываем об успехах и интересных событиях школьного дополнительного образования. На странице «О программе» вы узнаете об учебном плане объединения. Список выполненных в объединении «Экология» работ с именами авторов и соавторов приведен на странице «Наши работы», а «Фотоархив» представляет иллюстрации этапов выполнения школьных исследований. Страница «Это интересно» задумана для размещения образовательных ресурсов. Сейчас здесь можно найти интерактивную программу для изучения почвы «Почва, живая кожа Земли» на английском языке и электронный ресурс «Шкала масштабов Вселенной V.2» на русском, а также видеоинформацию по географии, экологии и почвоведению. На странице «Библиотека» мы собираем интересные книги и статьи по биологии и экологии. Со страницы «Полезные ссылки» можно попасть на дружественные и полезные интернет-ресурсы. На сайте можно найти информацию о большинстве проведенных исследовательских работ.

\section{Докучаевские молодежные чтения как информационная площадка для школьных экологических работ}

Десять лет автор курирует школьную секцию на молодежных Докучаевских чтениях Санкт-Петербургского государственного университета. Ученики докладывают на этой конференции результаты исследовательских работ по почвенным или водным

\footnotetext{
Наиболее тесным сотрудничество было с М.В. Агеевой (заведующая музеем истории школы 416), Н.В. Лебедевой (учитель химии в школе 412 , методист района), А.С. Красовой (учитель биологии и химии в школе 416), И.В. Клименко (учитель биологии в школе 416), Н.Д. Каверзовой (учитель биологии в Гимназии императора Александра II), С.В. Каргиной (учитель географии в Гимназии императора Александра II).

Дизайн и техническое обслуживание сайта ведет ученик 8 класса 542 школы Э. Доморацкий.
}

системам. В последние годы из-за большого количества участников темы докладов ограничены почвенной тематикой.

\section{Уникальность мероприятия}

Уникальность работы школьной секции при Докучаевских молодежных чтениях состоит в длительном подготовительном этапе, предшествующем конференции: проведение многих работ, а также подготовка публикаций всех тезисов курируется сотрудниками кафедры почвоведения и экологии почв и кафедры агрохимии СПбГУ [5]. Руководители кружков экологии могут обратиться к сотрудникам университета за консультациями по планированию работы, определению почвенных объектов, полевому описанию почв, выбору методик проведения анализов.

Важной чертой мероприятия является его безоценочность. Сейчас проводится масса конкурсов, многие из которых платные, где работы ранжируются по определенным критериям. Такие конкурсы хороши для сложившихся юных исследователей-победителей, но у прочих участников могут вызывать стресс, негативные эмоции и сформировать нежелание в дальнейшем заниматься подобной деятельностью. Между тем популяризация знаний о почве чрезвычайно важна в современном обществе. Кроме того, воспитание интереса к науке бывает критично в начале исследовательского пути. Обсуждение актуальности и проблем выбранной темы, не связанное с определением лидера «кто лучше выполнил исследование», помогает выявить возможные погрешности и ошибки работ, наметить перспективы продолжения. Наша конференция важна для поддержания этапа работ в форме свободной дискуссии.

\section{Историческая справка об участии школьников в Докучаевских молодежных чтениях}

Докучаевские молодежные чтения - ежегодная конференция, проводится с 1998 г. Время проведения приурочено ко дню рождения основателя почвоведения Василия Васильевича Докучаева, 1 марта. На пленарных заседаниях выступают с докладами ведущие ученые России и наиболее талантливые молодые сотрудники и студенты. Чтения посвящены обсуждению актуальных научно-практических проблем исследования почв и почвенного покрова, разработке концепции экосистемных функций почв, вопросам сохранения и повышения плодородия почв. На секционных заседаниях чтений принимают участие студенты и молодые ученые из различных регионов России. В 2014 г. прошли XVII чтения. Начиная с 2003 г. наряду со студентами в чтениях принимают участие учащиеся школ и экологических кружков. С 2004 г. школьные работы обсуждаются на отдельных заседаниях. В начале нашей работы мы заслушивали по 12-13 докладов, а число участников было 20-30. С 2009 г. число подаваемых заявок так возросло, что все работы на одном заседании заслушать стало невозможно. Поэтому были организованы две подсекции: на одной, по общей экологии, представлены геоботанические, агрохимические, гидрологические и почвенные работы, на другой - исследования исключительно по почвоведению. С 2010 г. к рассмотрению стали принимать только профильные работы по почвоведению, экологическому почвоведению и агрохимии. Например, в 2011 г. на школьные секции 
было предоставлено 32 доклада практически только почвенной или агрохимической тематики. Обширна география мест, откуда приезжают юные исследователи. Школьную секцию, как и студенческую конференцию, по праву можно назвать Всероссийской с международным участием. К нам приезжают учащиеся из Уфы, Беларуси, Молдовы, Белгорода, Волгограда, Перми, Костромы, Черняховска, Краснодара и др. Большая часть работ бывает представлена школьниками Санкт-Петербурга и Ленинградской области.

Приятно отметить общий деловой настрой, когда дети выступают с докладами, слушают друг друга и отвечают на вопросы очень серьезно. Нельзя не сказать о некоторых назревающих в школьном дополнительном образовании проблемах. Это заметно не только на нашей конференции, но и на городских олимпиадах. Бывает, что школьные исследовательские работы стараются охватить глобальные проблемы, такие, решение которых под силу большим профессиональным научным коллективам. Ребята могут использовать научную терминологию, не вполне понимая ее смысл. Очень бы хотелось, чтобы в школьных работах изучались простые понятия, но более детально, более подробно, так чтобы у ребят стало привычным тщательное, «вкусное» изучение природы, ее объектов и явлений. Конечно, главная цель подобных собраний - поддержать интерес к почвоведению и экологии, возможно, в чем-то поправить и улучшить сделанные работы. Помочь в выборе будущей специальности.

Каждый год участники чтений награждаются дипломами, им вручают сборники тезисов докладов конференции. По отзывам руководителей школьных работ «конференция дает ребятам возможность знакомиться с опытом исследования жизненно важных природоохранных вопросов, решать реальные проблемы, а не просто участвовать в олимпиадном движении».

\section{Заключение}

Главная задача работы объединения «Экология» распространение норм экологической этики. Теоретически все знают, что мусорить нехорошо, редкие и красивые цветы лучше фотографировать, а не рвать, ко всему живому миру вокруг надо относиться бережно. На практике же многие думают, что лично для него можно сделать исключение: «подумаешь, бросил бумажку», «подумаешь, сорвал букетик», «подумаешь, развел костер»... Иногда и ребята, и взрослые говорят: мы так и будем плохо жить, это извечные проблемы, у нас такой менталитет. И тут же вспоминают, что в других странах чище, к природе относятся бережнее, и что когда сами они попадают за границу, то и экологическое поведение изменяют. Значит, дело не в менталитете как вечном тормозе и барьере. Нужно менять уровень понимания важности экологических проблем каждому человеку. Законы, регулирующие общественное поведение, налагающие штрафы на нарушителей, конечно, тоже важны. Но ко всем по воспитателю не приставишь, каждому нужны сознательность и самоконтроль. И любовь к природе и стране. Как бы пафосно это ни звучало. И здесь любые средства экологического обучения и просвещения хороши. Проекты идеальной жизни, воздушные замки строятся в облаках. Это нормально, им там самое место, пусть они там и остаются. Наше дело - подвести под них фундамент.

\section{Литература}

\section{Список русскоязычной литературы}

1. Алексеев СВ, Груздева НВ, Гущина ЭВ, Шиленок ТА. Состояние дошкольного и школьного экологического образования в Санкт-Петербурге. Биосфера.

2. Добровольский ГВ, ред. Почва, город, экология. М.: Фонд «За экономическую грамотность»; 1997.

3. Любжин АИ. Полемика о проекте стандарта старшей школы. Вопросы образования. 2011;(2):183-93.

4. Надпорожская МА, Слепян ЭИ, Ковш НВ. О почвах исторического центра Санкт-Петербурга. Вестник СПбГУ Сер 3. 2000;(1):116-26.

5. Надпорожская МА, Федорос ЕИ. Концепция проведения школьной секции как составной части ежегодных Докучаевских молодежных чтений. В кн.: Материалы по изучению русских почв. Ред. Апарин БФ. - СПб.: Изд-во СПбГУ; 2014. с. 49-53

6. Петров К.М. Философские проблемы географии. Натурфилософская парадигма. СПб.: Из-во СПбГУ; 2005.
7. Розенберг ГС, Гелашвили Д, Краснощеков ГП. Крутые ступени перехода к устойчивому развитию. Вестник РАН. 1996;66:436-40.

8. Титлянова АА. Универсальность процессов биотического круговорота. Почвоведение. 2014;7:771-80.

\section{Общий список литературы/Reference List}

1. Alekseyev SV, Gruzdeva NV, Guschina EV, Shilenok TA. Environmental education at municipal preschool institutions and schools in Saint Petersburg. Biosfera. 2014;6:89-105.

2. Dobrovolskiy GV (ed.). Pochva, Gorod, Ekologiya. Moscow: Fond "Za Ekonomicheskuyu Gramotnost"; 1997.

3. Liubzhin AI. [Polemics about a standard of high school]. Voprosy Obrazovaniya. 2011;(2):183-93. (in Russ.)

4. Nadporozhskaya MA, Slepyan EI, Kovsh NV. [On soils in the city of Saint Petersburg]. Vestnik SPbGU Ser 3. 2000;(1):116-26. (in Russ.)

5. Nadporozhskaya MA, Fedoros YeI. [A concept of schoolchildren session as a part of annu- 
al Dockuchayev Readings for young scholars]. In: Materialy po Izucheniyu Russkikh Pochv (ed. by Aparin BF). Saint Petersburg: Izdatelstvo SPbGU;2014. p. 49-53. (in Russ.)

6. Petrov KM. Filosofskiye Problemy Geografii Naturfilosofskaya Paradigma. Saint Petersburg: Izdatelstvo SPbGU;2005. (in Russ.)

7. Rozenberg GS, Gelashvili D, Krasnoschekov GP. [Steep steps of transition to sustainable development]. Vestnik RAN. 1996;66:436-40. (in Russ.)

8. Titlianova AA. [The universal nature of biotic turnover processes]. Pochvovedeniye. 2014;7:771-80. (in Russ.)

\section{Приложение}

\section{ПУБЛИКАЩИИ УЧАЩИХСЯ ОБЪЕДИНЕНИЯ «ЭКОЛОГИЯ}

\section{Материалы международной научной конференции «XVII Докучаевские молодежные чтения». СПб.; 2014.}

1. Агеев ГК, Надпорожская МА. Особенности формирования качества воды в английском пруду. с. 326-7.

2. Акмазикова ЕС, Надпорожская МА, Клименко ИВ. Пруд Бауш в Старом Петергофе история и экология. с. 327-8.

3. Алиева ФС, Чемакина ЛА, Дубинина ЕС, Надпорожская МА, Клименко ИВ. Кроты парка Александрия. с. 328-9

4. Близнякова ДС, Надпорожская МА, Лебедева НВ. Проблемы сорных растений на клумбах Петергофа. с. 329-30.

5. Доморацкая ДА, Надпорожская МА. Сорные позднелетнецветущие растения в городе. c. $346-7$.

\section{Материалы IX Международной} экологической Школы-конференции в усадьбе «Сергиевка» - памятнике природного и культурного наследия: «Сохранение природной среды и оптимизация ее использования в Балтийском регионе». СПб.: Изд-во ВВМ, 2014.

1. Доморацкий Э, Надпорожская МА. Информационное сопровождение школьных исследовательских проектов. с. 318-20.

2. Акмазикова Е, Надпорожская МА, Клименко ИВ. Экологическое состояние территории коттеджного комплекса «Сад времени» в Старом Петергофе. с. 300-2.

3. Раевский К, Семенов А, Надпорожская МА, Кожина ОБ. Контроль разрастания экологически агрессивных растений парка Сергиевка. с. 357-9.

4. Стадник Е, Федоренко К, Дубинина А, Надпорожская МА. Экологические проблемы мест летнего отдыха - пляжей. с. 366-8.
5. Агеев Г, Надпорожская МА, Каргина СВ. Учет численности крякв на Ольгином пруду в Петергофе. с. 297-9.

6. Брежнева А, Харчевникова Д, Шевченко Е, Надпорожская МА. Транзитная ливневая канализация Сергиевки - нефтяной след? с. 312-4.

7. Красова Е, Надпорожская МА, Красова АС. Опыт реинтродукции раннецветущих растений на школьном дворе. с. 335-6.

\section{Материалы международной научной конференции XVI Докучаевские молодежные чтения. СПб.; 2013.}

1. Близнякова ДС, Надпорожская МА, Лебедева НВ. Проблемы озеленения Нового Петергофа: клумбы - красивые или ужасные? c. 206-7.

2. Доморацкая ДА, Надпорожская МА. Проблема сорных позднелетнецветущих растений в городе. с. 211-2.

3. Дубинина ЕС, Надпорожская МА, Лебедева НВ. Оценка экологического состояния почв парка Александрия (Новый Петергоф). с. 212-3.

4. Красова ЕК, Брежнева АВ, Надпорожская МА, Красова АС. Влияние строительных работ на качество поверхностных вод. с. 217-8.

5. Купатадзе ЕБ, Надпорожская МА, Каверзова НД. Проблема зарастания мхом грунтовых дорожек - экологически оптимальные решения. с. 222-3.

6. Реуф ОС, Ганина КВ, Кнурова АЮ, Клименко ИВ, Надпорожская МА. Школьный двор - история, экология, традиции. с. 231-2.

\section{Материалы VIII ежегодной молодежной экологической Школы-конференции «Современные проблемы сохранения биоразнообразия естественных и трансформированных экосистем». СПб.: Изд-во ВВМ, 2014.}

1. Близнякова Д, Надпорожская МА, Лебедева НВ. Проблема сорных растений при благоустройстве зеленого наряда Петергофа. с. 303-5.

2. Акмазикова E, Надпорожская МА, Клименко ИВ. Нужен ли пруд Бауш в Старом Петергофе? с. 297-9.

3. Озеров С, Надпорожская МА. Осы парка Сергиевка. с. 339-41

4. Раевский К, Семенов А, Календарев И, Кожина ОБ, Надпорожская МА. Экологически агрессивные сорные растения в парке Сергиевка. c. $346-8$.

5. Мулык Е, Надпорожская МА. Раннецветущие растения в Петергофе (на примере Верхнего парка и прилегающей территории). с. 337-8.

6. Алиева Ф, Чемакина Л, Дубинина Е, Надпорожская МА, Клименко ИВ. Кроты парка Александрия. с. 300-2.

7. Агеев Г, Надпорожская МА. Особенности формирования качества воды в Английском пруду. с. 395-6. 
8. Стадник Е, Надпорожская МА. Тайны постройки здания фермы в Сергиевке и экологические вопросы. с. 355-7.

\section{Материалы международной научной конференции XV Докучаевские молодежные чтения.}

СПб.; 2012

1. Головацкая ДА, Купатадзе ЕБ, Каргина СВ, Надпорожская МА. Как предотвратить зарастание грунтовых дорожек школьного двора. с. $327-8$.

2. Маликова МC, Тарасова МВ, Погонченко НЭ, Румянцев МД, Терехов МА, Каверзова НД, Надпорожская МА. Диагностика экологического состояния школьного двора по разнообразию макромицетов. с. 339-40.

3. Реуф ОС, Ганина КВ, Кнурова АЮ, Клименко ИВ, Агеева МВ, Надпорожская МА. Повышение функциональности школьного двора. C. 344-5.

4. Филенко ММ, Иванов АА, Хаджимирзоев РР, Красова АС, Агеева МВ, Надпорож- ская МА. Изучение пустыря на улице Жарновецкого в Новом Петергофе. с. 349-50.

5. Шейнов РА, Галичкин ОА, Апасаликова TM, Надпорожская МА. Наблюдения за мощностью снегового покрова в саду 300 -летия Петергофа. с. 354-6.

\section{Материалы VII региональной молодежной конференции «Экологическая школа в Петергофе - Наукограде Российской Федерации». СПб.; 2012.}

1. Купатадзе ЕБ. Зарастание грунтовых дорожек школьного двора. с. 243-5.

2. Маликова М, Притула А. Макромицеты городской территории на примере двора гимназии в Новом Петергофе. с. 339-40.

3. Доморацкая ДА. Проблема сорных позднелетнецветущих растений в городе. с. 219-21.

4. Дубинина Е. Оценка экологического состояния почв парка Александрия (Новый Петергоф). с. 222-4.

5. Красова Е, Брежнева А. Влияние человека на качество поверхностных вод. с. 236-8.

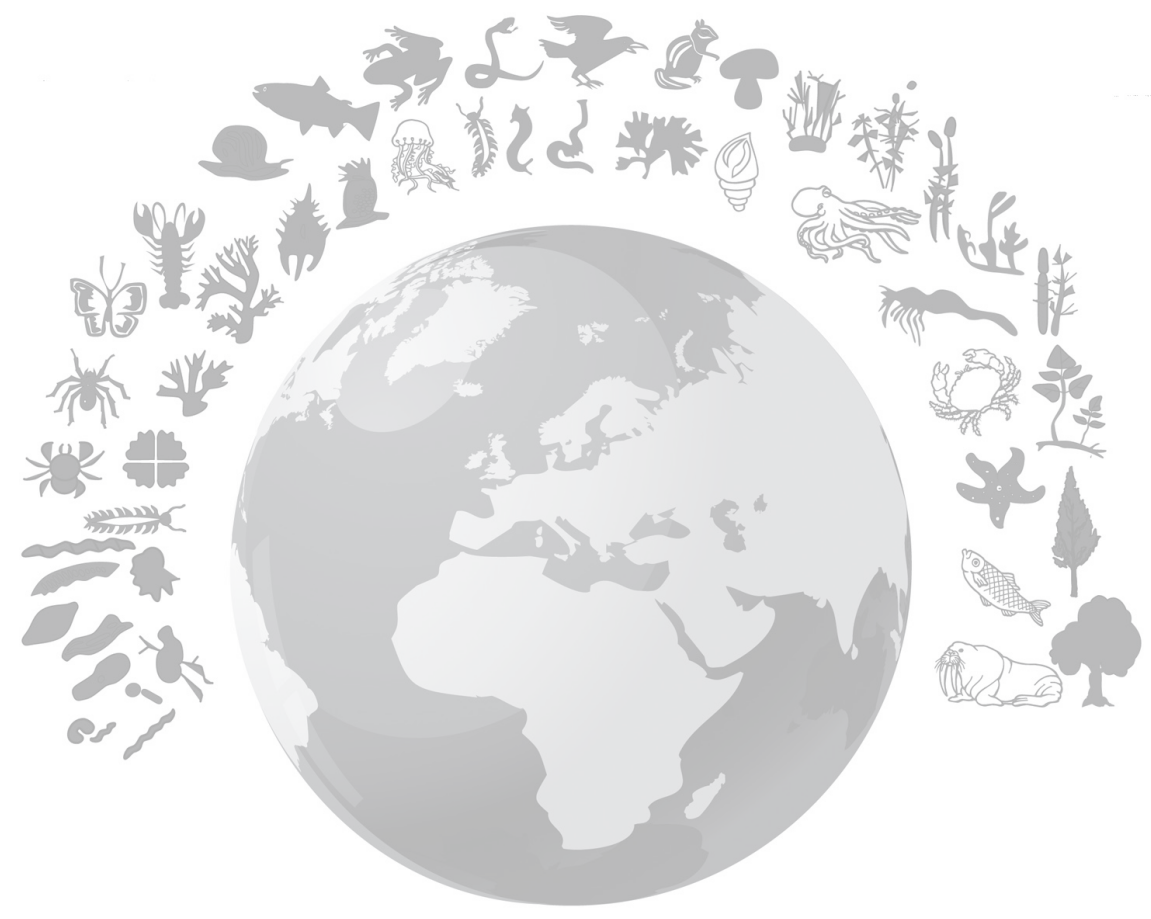

